\title{
Post Report Update Date
}

National Cancer Institute

\section{Source}

National Cancer Institute. Post Report Update Date. NCI Thesaurus. Code C93629.

The date (and time) on which report was updated after it had been submitted. 